\title{
Development and modification in therapeutic antibodies to combat various diseases
}

\author{
Ghulam Akbar ${ }^{*}$, Muhammad Anjum Zia ${ }^{1}$, Ali Ahmad ${ }^{2}$, Sana Ahmad ${ }^{1}$, \\ Aamna Rafique ${ }^{1}$, Neha Arooj ${ }^{1}$ and Shahneela Nusrat ${ }^{1}$ \\ 1. Department of Biochemistry, University of Agriculture, Faisalabad, 38000-Pakistan \\ 2. Department of Agronomy, University of Agriculture, Faisalabad, 38000-Pakistan \\ *Corresponding author's email: ghulamakbardgk@gmail.com \\ Citation \\ Ghulam Akbar, Muhammad Anjum Zia, Ali Ahmad, Sana Ahmad, Aamna Rafique, Neha Arooj and Shahneela \\ Nusrat. Development and modification in therapeutic antibodies to combat various diseases. Pure and Applied \\ Biology. Vol. 9, Issue 3, pp2097-2110. http://dx.doi.org/10.19045/bspab.2020.90224
}

\begin{tabular}{llll}
\hline Received: 02/03/2020 & Revised: 30/05/2020 & Accepted: 08/06/2020 & Online First: 17/06/2020
\end{tabular}

\section{Abstract}

In 1986, as the initial monoclonal antibody was accepted by the United States Food and Drug Administration (US FDA), and this time antibody engineering has intensely evolved. Among rapidly emerging therapeutic techniques, antibody engineering based treatment is the best one which is being used to cure human disorders. Antibodies are antigen identifying immunoglobulins which have various repertoire domain capable of antigen specificity. This diverse antibody response is more increased by modifications including somatic recombination, hyper-mutation and post-translational modifications like Fc glycosylation may further upsurge the diversity of effector functions. However, variations in glycan structures effectively helps to the antibody's functional capabilities. Glycosylation is the modification in protein after the translational process during antibodies synthesis. Glycosylated antibodies play a major role in improving efficiency, pharmacokinetics and safety of curative antibodies. In the pharmacological industries, the regulation and adjustment of therapeutic antibodies is the key point in antibodies engineering. In this review article the recent approaches and novel antibody $\mathrm{C}$-terminals and $\mathrm{N}$-terminals modifications, and their impact on half-life, immunogenicity and effector functions have been discussed. Moreover, the recent progresses in the glycosylation and glycosylation control along with the risk assessments have also been described here.

Keywords: Antibody engineering; Glycosylation; improved efficacy; pharmacokinetics;

Therapeutic approaches

\section{Introduction}

There are many forms of recombinant antibodies which have been developed for the therapeutic purpose. A class of immunoglobulin antibodies known as $\mathrm{IgG}$ most widely used for the preparation of recombinant $\mathrm{IgG}$ antibodies in different vector expression systems. The structure of IgG has two light chains and two heavy chains. It also has two regions one called as constant region and other is called variable region based on its amino acids composition and sequence. These regions further differentiated into fragment antigen binding 
(Fab) region (which bind and recognize specific antigen) and fragment crystallizable (Fc) region (which help to control activity of defense cells). In the constant area of heavy chain, IgG antibodies have $\mathrm{N}$-glycans in the Fc domain and their N-glycosylation patterns differ during various cell expression systems. Among main therapeutic agent monoclonal antibodies (Mabs) play a key role for several fatal diseases like AIDS (acquired immune deficiency syndrome), cancer and infectious diseases [1]. There is a unique site within the $\mathrm{Fc}$ region to which $\mathrm{N}$-glycans are linked. These $\mathrm{N}$-glycans are important for $\mathrm{IgG}$ effector function. The structural study with NMR (nuclear magnetic resonance) and Xray crystallographic shown that $\mathrm{Fc} \mathrm{N}$-glycans are present within $\mathrm{CH}_{2}$-domain of each heavy chain. This study also reveal that Fc Nglycans contain several noncovalent bonds with $\mathrm{Fc}$ domain for the maintenance of its conformational flexibility. Therefore, in the transgenic cell systems and biopharmaceutical industry, glycosylation is the chief concern. For the remodeling of antibodies yeast, insect and plant cells are most commonly used. For engineering these antibodies specific core fucose are truncated, and also sialylated and galactosylated branches are declined. A very dangerous thing is that these cell lines produce antigenic glycoproteins (terminal Gala1-3Gal, NeuGc epitope, etc) which are different to human glycoproteins. These antigenic glycoproteins badly affect immune system. However, by the interference of several endogenous glycolinked molecules (nucleotide sugar, glycosidase, glycosyltransferase and protein trafficking) and remodeling of mAbs (monoclonal antibodies) with homogeneous glycans is not easy while using a cell expression system.

Currently, curative mAbs capable to represent specific Fc N-glycan have been engineered by using site-specific gene knockout approaches in various cell expression systems [2, 3]. For their effective treatment against bacterial and viral diseases the use of monoclonal antibodies (mAbs) is emerging technique in medicinal industries [4]. In recent years USA and Europe over 60 mAbs were accepted having some great commercial success in the pharmaceutical market $[5,6]$. Usually recombinant $\mathrm{mAbs}$ are formed with the combination of immunoglobulin $\mathrm{G}$ and glycans linked to asparagine's amide in the Fc region [7]. The different glycoforms can give antibodies some peculiar storage and physicochemical stabilities. Glycans play structural role as they link $\mathrm{CH} 2$ domains with detailed weak connections. Such interactions reduce the $\mathrm{CH} 2$ flexibility and facilitate its folding. Structural features, explain the decreased chemical as well as thermal stability $[8,9]$. $\mathrm{N}$-glycan may affects the PK of IgG by regulating the modulation of $\mathrm{IgG}$ sensitivity to serum protease. Glycosylated IgGs have increased resistant than the aglycosylated IgGs [10]. Susceptibility of IgGs to proteolysis depends upon three factors like length, branching, and charge on sugar subunits. Hepatocytes have special asialoglycoprotein receptors that can bind and clear $\mathrm{IgG}$ with terminal galactose residue [11]. Moreover, mAbs glycosylation is also found to be correlated with immunogenicity and safety in humans. There are some approaches by which therapeutic monoclonal antibodies are developed shown in (Fig. 1).

\section{N-terminal modifications}

$\mathrm{N}$-terminal of mAb can be modified by two ways.

1. Pyroglutamate (pyroGlu) amino acid at the first position of the mature light or heavy chain.

2. Unprocessed leader sequences.

Spontaneous cyclization of side chains of glutamine and glutamate amino residues onto $\alpha$-amines produces Pyroglutamate [12]. Cell culture provides neutral $\mathrm{pH}$ with high temperatures, which favour such reactions 
[13]. Cyclization of glutamate can also be done but this reaction proceed at a much slower rate $[14,15]$. Genome of the host organism has $\mathrm{mAb}$ transgenes, which contains sequence that guides the protein in secretion procedure. Mostly this leader sequence is removed by proteolysis when recombinant $\mathrm{mAbs}$ is secreted into the cell culture broth. But sometimes, this 10-15 amino acids are not processed completely, resulted in altered leader sequence antibodies
[16]. Rarely, miscleavages culminates in truncation [17, 18]. Immunogenicity concerns or this modification are minimized as N-terminal glutamine is mostly transformed to pyroGlu when it comes to human endogenous immunoglobulin ( $\operatorname{IgG}$ ) [19]. Both modifications actually produce polar molecules resulted in accumulation and mis-cleavage causes product heterogeneity and so must avoided.

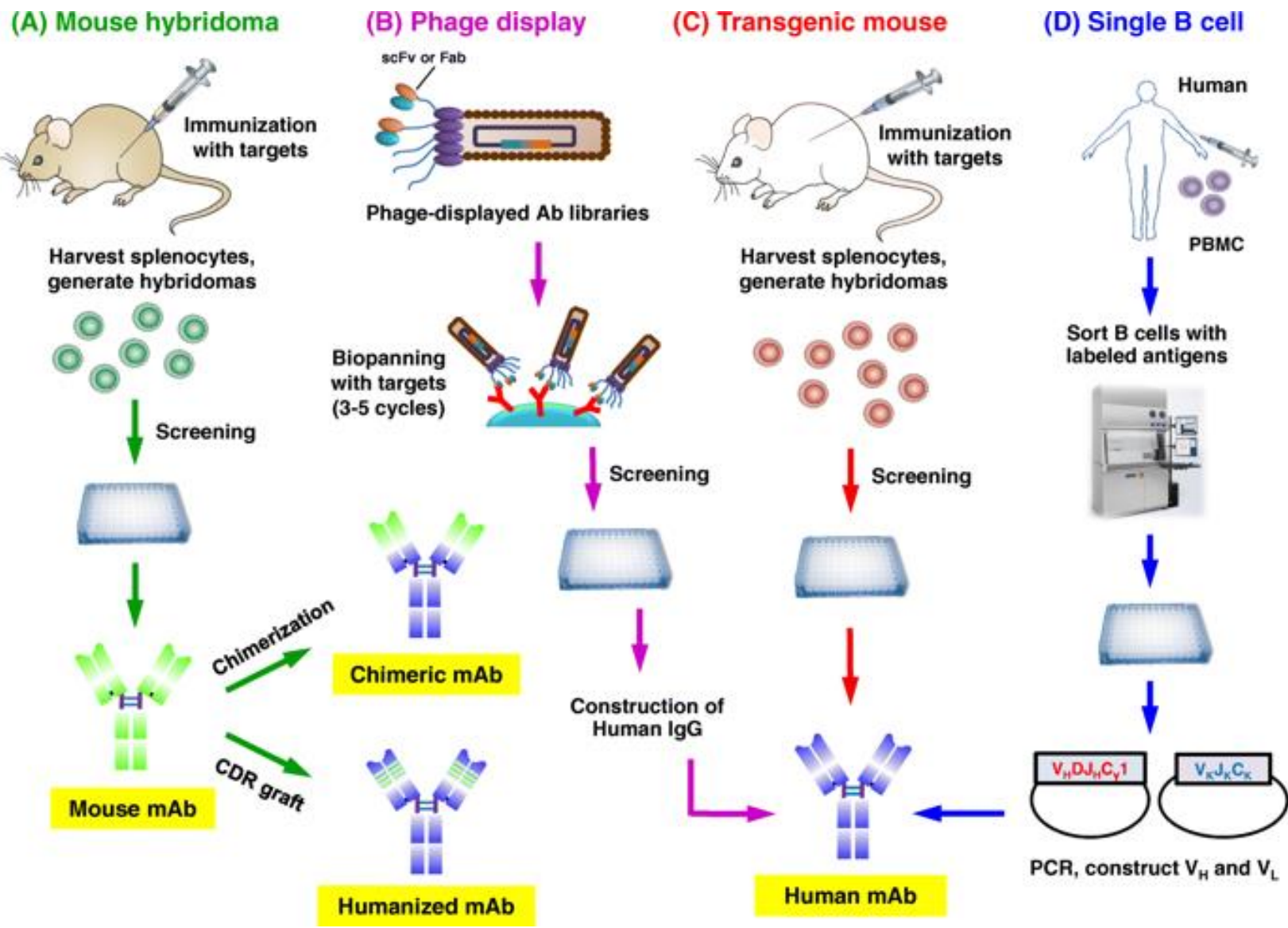

Figure 1. Different Methods to develop mAb antibodies. a is a mouse hybridoma technique that trigger immunity against specific antigens. $b$ Phage display method: here phage library is prepared for the selection of desired antigen, $c$ Transgenic mouse; it is identical to single $B$ cell approach, $d B$ cell method in which vaccinated donors are designed for the separation of $B$ cells [12]

\section{C-terminal modification}

There are two major C-terminal modifications one is the removal of lysine on C-terminal and the other is Amidation at C- terminal. There is a terminal lysine residue in heavy gamma chain of IgG genes. But terminal lysine is removed by the application of enzymes and human IgG in the blood does 
not have it [20]. Almost all recombinant genes include a terminal lysine that is separated during cell culture [21] and it can be partial with zero to multiple lysine residues. Lysine residues impart positive charge and can be detected by charge based biochemical techniques [22]. One more common modification of recombinant mAbs is the amide modification of antepenultimate residue. Glycine, proline and leucine modifications also results with all others [2325]. Because of the act that $\mathrm{C}$-terminal amino acids of $\mathrm{IgG} 2 \mathrm{~s}$ and $\mathrm{IgG} 3 \mathrm{~s}$ are the same as that of $\mathrm{IgG} 1 \mathrm{~s}$, amide modification is more prone to occur on the C-terminal of heavy chain. Charge based methods can also be used to detect C-terminal alpha amidation [24]. These modifications do not affect physical properties and $\mathrm{Fc}$ receptors and receptor binding sites. No structural diversity was observed in antibody by hydrogen-deuterium exchange [26] and differential scanning calorimetry [27]. It is also observed that the lysine amino acid at carboxy terminal has no effect on the binding of antigen and was also depicted that the efficiency is not affected by C-terminal Lys [28]. However, a study concluded that this removal is necessary for efficient binding of $\mathrm{Clq}$ and cytotoxicity [29]. In another detailed study it was demonstrated that efficiency and kinetics is not affected by the removal of C-terminal Lys, along with preceding glycine (Gly). However, thermal stability can be decreased depending on the specific [29]. Interestingly, antibodies showed decreased expression, slower synthesis and faster degradation, when constructed from C-terminal Lys lacking codon [30]. The whole In vivo IgGs processing are always without Lysine 20 terminal but still such an amide modification has not been demonstrated in humans [25] although it is usually present in hormonal peptides [31]. Here in (Fig. 2) is a detailed summary of antibodies development and progression with successful therapeutic applications.

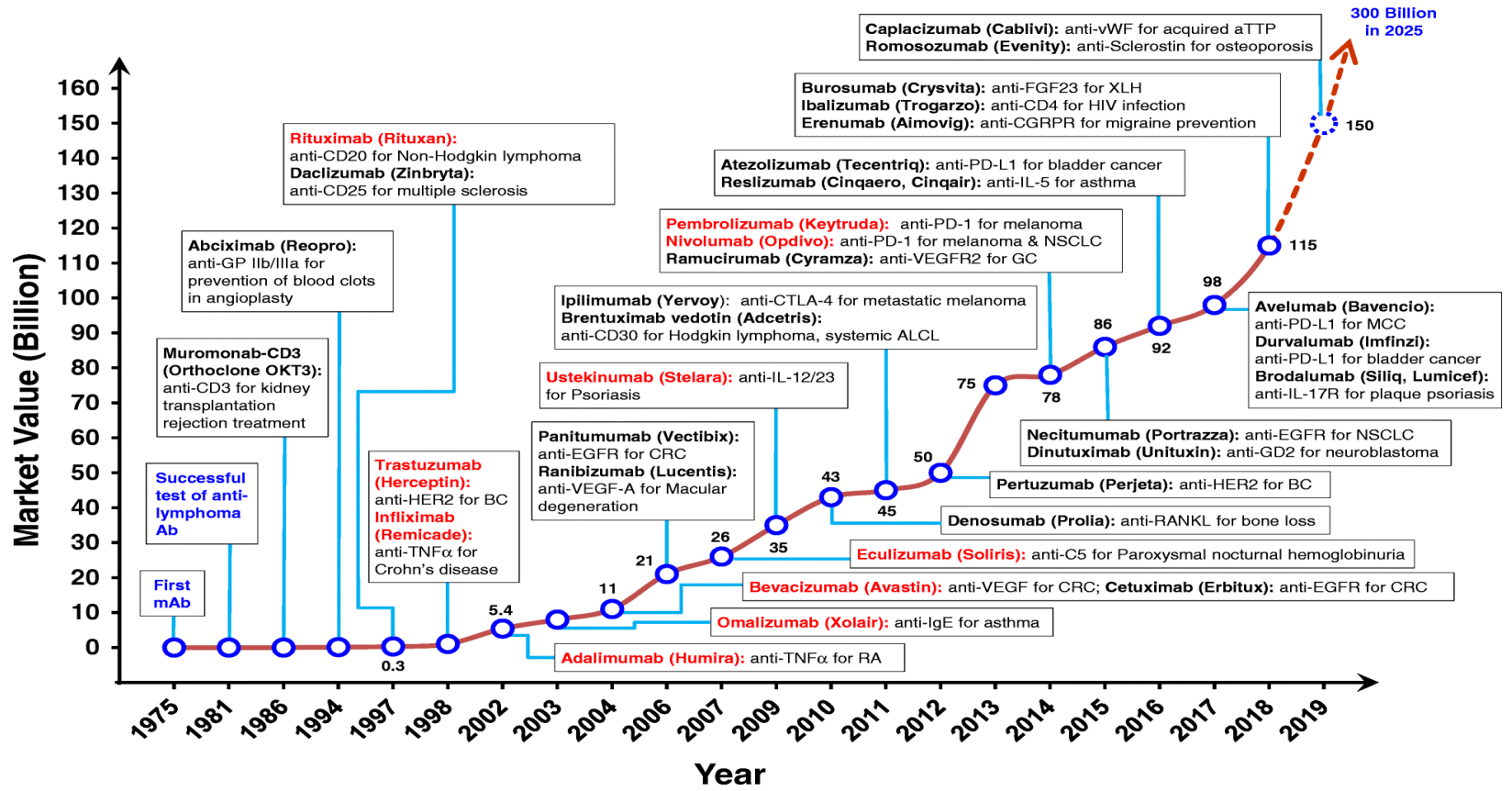

Figure 2. History of effective antibodies developed from 1975 to 2019 in which line height is representing commercial value in billion dollars. Top ten most selling therapeutic antibodies are shown in red color [18] 


\section{Effect of modifications on antibodies effector functions}

Glycoforms having crystallizable fragments, these fragments affect the activities of the antibodies by changing detailed structure of $\mathrm{Fc}$ receptors. In this way, brings alteration in the interactions of $\mathrm{Fc}$ receptor-ligands. The details of structure justifying that how antibody Fc plays a role in effecting the functions, these details have been obtained by different techniques like NMR (nuclear magnetic resonance) spectroscopy. The basic structures of GlcNAc2Man3 (N-acytyl glucosamine derivative) can be seen more clearly and distinguished in the forms of crystals due to protein-sugars stabilization effects. These two arms acquire peculiar orientations in $\mathrm{CH}_{2}$ dimer the 1,3 arm is placed towards the inner space and 1,6 arm hangs over the hydrophobic (water repelling) face [32]. The oligosaccharide is spans over $500 \AA 2$ on the surface of $\mathrm{CH}_{2}$ domain and is well conserved. They form several hydrophobic as well as non-covalent and polar bonds with the internal surface of $\mathrm{CH}_{2}$ domain. Strong bonds are D265 hydrogen bonding with the internal face of GlcNAc and $\alpha-1,6$ arm forming strong $\mathrm{CH}-\pi$ folding with Phe241 and 243, which concludes in restricted movement of glycans. Such intramolecular interactions hinder the $\mathrm{CH}_{2}$ conformation by modulating the Asn297 containing $\mathrm{C}^{\prime} \mathrm{E}$ loop, by which $\mathrm{N}$-glycans modulate the ligands binding surface on $\mathrm{Fc}$ receptors [33].

Moreover, carbohydrate-carbohydrate interactions also play an important role to organize the Fc configuration. The corresponding mannoses with two different heavy chains form important $s p-s p$ connections, which necessary for Fc conformation and thus, receptor-ligand are binding. Terminal sugars have a diversity of impacts in on the antibody effector function. The end chain of sialic acid lowers ADCC (antibody- dependent cellular cytotoxicity) of
IgG and lows fucose, highs mannose, bisecting GlcNAc highers ADCC because of the high FcyRIIIa binding [34]. End of galactose residues increase CDC (complement-dependent cytotoxicity) functioning by enhancing $\mathrm{Clq}$ binding, whereas terminal sialic acid and GlcNAc decrease it [35]. Among effects as mentioned above, decrease in fucose (hexose deoxysugar found on $\mathrm{N}$-linked glycan of mammalian, insect or plant cell surface) and end chain of galactose which improves ADCC and CDC, is highly demanding in antibody [36].

\section{Effect of modifications on antibodies half- life}

Full-length IgG antibodies mostly have longer half-lives extending to weeks, than half lives of small-molecular cytokines [37]. One of the reasons behind this fact is that vascular endothelial cells and macrophages express neonatal $\mathrm{Fc}$ receptor $(\mathrm{FcRn})$ which binds IgGs. Receptor FcRn binds IgG antibodies through endosomal compartment $\mathrm{pH}$-dependent interactions which prevent antibodies from enzymatic degradation, brings antibodies to the periphery of the cell and regulate it. Another point to be noted is that sometimes modifications as $\mathrm{N}$ glycosylation affect half-life [38]. Antibodies with sialic acid at end have showed a relatively longer half-life than that of antibodies without sialic acid. A decrease in half-life is seen due to the endocytosisregulated degradation of the glycoprotein. The sialic acid at the terminal end protect antibodies from the rapid clearance covering up the galactose [39]. In glycoengineered P. pastoris strains, Liu et al. produced recombinantly modified $\mathrm{Fc}$ fusion proteins also known as TNFR2. There was found a relation between content of sialic acid (an acidic sugar with a nine carbon backbone) and the kinetics of the rat's proteins [28]. Antibodies having high degree of mannose at ends show quicker blood clearance. The 
mannose receptor, an endocytic glycan receptor is expressed in many tissues. The receptor binds different monosaccharides including mannose, fucose, and $\mathrm{N}$-acetyl glucosamine (GlcNAc, derivative of glucose) and has a total of 10 extracellular domains including a repeat domain, cysteine containing domain and carbohydrate identification domains [40]. A study showed that presence of mannose content in $\mathrm{Fc}$ region lowers the half-life. Yu et al. produced high degree of mannose content antibodies through inhibitor targeting mannosidase. The scientists found out the relation that having high-mannose antibodies clear comparatively faster than those having a complex glycoform specifically fucosylated. Moreover, the pharmacokinetics of antibodies with Man8/9 glycoform show similarity to those of Man5 antibodies. Mouse serum having mannosidase converts most Man8/9 to Man6 after $24 \mathrm{~h}$ [41]. However, Yang et al. showed that antibodies having "2-imino-2-methoxyethyl-1thiomannoside", to maintain glycosidic bond clear faster than anti bodies having mannose. Therefore, scientists have contradictory conclusion that may be glycosylation isn't related to the clearance of therapeutic proteins [42]. Thus, the role of mannose in pharmacokinetics (PK) of antibodies and its mechanism is still to be verified and elucidated.

\section{Effect of modifications on antibodies} immunogenicity

Post translational modifications of antibodies affect its features like function, structure, interaction and immunogenicity [43]. This antigenicity is caused by oligosaccharide subunits linked with antibodies trigger immune reactions $[44,45]$. In case of medicinal glycoproteins with antigenic nature limits its efficiency and uses [46]. In this scenario when therapeutic antibodies are present in the body if anti-drug antibodies are developed neutralize these therapeutic antibodies and consequently the efficacy of therapeutic antibodies decreases [47, 48]. However, glycosylation makes protein aggregation which affects the engineered antibodies stability. This formed protein clump is a main cause of antigenicity [49]. Antibodies expressed in non-human source have glycoforms which initiate immune responses in human bodies for example $\mathrm{N}$ glycolylneuraminic acid (Neu5Gc) [50-52].

\section{Control of antibody glycosylation}

This procedure of antibody glycosylation is a post- translational protein engineering which is occurred in host's cell [53]. Therefore, by using various hosts (human, animal or yeast cells), therapeutic antibodies can be designed [54-59]. For the generation of unique characteristics glycans, genome edited hosts with their certain glycosylation pattern are used [60]. Various host cells have ability to synthesis numerous glycoprotein patterns for example, $\alpha$ and gla, are produced by mouse SP2/0 cells (standard murine myeloma cell lines) and Neu-5Gc glycoproteins are produced by NS0 (non-secreting murine myeloma) [61]. For the advancement of clinical therapeutics properties of antibodies, cell lines modified for production of immunogenic glycoforms to attain target products. Now a days $\mathrm{CHO}$ (Chinese hamster ovary) cells are main targets to exhibit therapeutic antibodies, on other side in cell lines, production of biopharmaceutical proteins are near to $70 \%$ by recombinant techniques [62].

CRISPR/CAS9 is an emerging genome editing technique which is also used in a successful manner to modify the $\mathrm{CHO}$ cells recently by attenuate $\alpha$-sialylation and overexpress of $\alpha$-sialylated glycans to help the ADCC (antibody-dependent cellular toxicity) and anti-inflammatory capacities of antibodies [63]. Humanized glycosylation path and against human epidermal development factor receptor used to produce monoclonal antibodies by $P$. pastoris which 
had been engineered and results showed better ADCC bioactivity than trastuzumab [64].

Many research teams stated about FUT8 (fucosyltransferase 8) cells as an ideal host in CHO-DG44 cell line for production of stable, efficient defucosylated, high-ADCC antibodies for therapeutic use by homologous recombination [65-67]. Moreover different physiochemical conditions as like temperature, liquefied oxygen, nutritional level and $\mathrm{pH}$, also ensure significant effect on glycosylation of antibodies [68, 69]. The human cell line rF2N78 can take as an example for production of anti-bodies which are not glycosylated, enhanced in presence of glucose and this phenomenon can be avoided by feeding glucose [70]. So Glucose is essential for glycosylated antibodies production and the glycan pattern can be changed due to fluctuation in $\mathrm{pH}$ [71]. The production batch must be climatic to make sure the biochemical character and biological activity of antibodies because patterns of glycans can be distressed by the articulate system and conditions of culture. Glycoformic antibodies which made in host cells of mammals are not same with human serum immunoglobulin $\mathrm{G}$ glycoforms and some of them are immunogenic to humans.

Authentic analytical methods must be designed for evaluating the glycan patterns of antibodies. Half-lives of antibodies can be stabilized by glycans and the glycoform approach can also act as modulator of some satisfying properties of antibodies. For that reason, glyco-engineering is a rising technique for development of therapeutic antibodies. But the exertion of $\mathrm{N}$-linked glycans and glycosylation positions still make it difficult to apply. There is more research required to understand mechanisms related with the glycosylation of therapeutic antibodies. The consequences of laboratory studies must apply in medicinal industry to emerge the glyco-engineering.

\section{Progresses in glycosylation}

Different techniques can be used for the identification of glycans like with HPLC (high performance liquid chromatography) glycan not also identify by their retention time but can also quantify by their peak areas. But in case of database values it is necessary to compare retention time to the data [72]. Characterization of glycans can be done with capillary zone electrophoresis mostly with laser as an inducer in fluorescent detection [73]. Analysis of high polar compounds is commonly done with hydrophilic interaction liquid chromatography (HILIC), specifically for antibodies with a typical glycan pattern [74]. HILIC preferred than others HPLC methods due to its high resolution for analyzing free glycans [75]. MS (mass spectrometry) techniques are very popular for exploration of antibody glycosylation because of high sensitivity or efficiency but stereoisomers can't be identifying separately and non- MS-based techniques are not capable to identify unknown compounds. High performance anion-exchange chromatography is coupled with MS for the detection of less plentiful glycan species, for example bi-antennary complex-type, hybrid, high-mannose and hybrid bisected structures [76].

Therapeutic antibody is digested with a protease during glycopeptide analysis. After this the glycan is improved by RP-HPLC (reverse phase-high performance liquid chromatography) and glycopeptide is detected by MS afterward separation [77, 78]. To determine the glycosylation summaries of anti-PD-1 antibodies, ultrahigh performance liquid chromatography (UHPLC) is coupled with quadrupole time of flight MS and consistency of different passages of stable $\mathrm{CHO}$ cell lines authenticated [79]. To find the structure of glycoproteins and to site the monosaccharaides and their linkage, electrospray ionization mass spectrometry 
(ESI-MS) is suited for all these analysis. Molecular weights and their patterns can be determine by MS analysis [80]. Efficiency of original drugs can determine by comparing them with their reference drugs easily. Some other techniques of separation also coupled with MS for exploration of intact glycoproteins. As like Lectin microarrays which are coupled with a modified exposure system, which give specific plot for determination of the particular glycan variants by testing intact glycoproteins [39, 81]. In spite all of these advanced techniques; the characterization of $\mathrm{N}$-glycopeptides is still a challenge because of their micro heterogeneity, various glycoforms bond to one glycosylation site as well as different sites of the glycoprotein.

\section{Important quality attributes}

Critical quality attributes are prime parts of the quality with design method in ICHQ8 to Q10. Q8R (2) stated that CQA is a biochemical property that must be remain in suitable range to make sure the desired product caliber [82]. CQAs of drug ingredients can be approached by the effects of potency, safety and immunogenicity [83]. The annotation and estimation of mAb CQAs are not straightly linked with the product of the drug. Whether, CQAs of final product can be affected by condition or process of production. Extraction, leaching and cell culture admitting are actually solid CQAs but because of process parameters, these have a considerable effect on substance of product or impurities of product. Drug substance CQAs and process of production should be thoroughly studied to check association between them [84]. To enhance the product information, CQAs estimation could be done many times from clinical development. CQA estimation is targeted at maintaining, in an organized way, the effect of variations including capability, pharmacokinetic and pharmacodynamics.

\section{Risk-assessments}

It is a prime factor during planning process. Each CQA is count to check the efficiency of process and clinical results during risk assessment. Risk is stated as "the combination of the probability of occurrence of harm and the severity of that harm." Risk assessment is a continue process, defining the quality risk management as an organized process for estimation, charge, articulation and checkup of risks to the quality of the final product beyond the product lifecycle [85]. The class of risk must be depends upon precise knowledge connected to the safety of the people. The effect of changes in product quantity is integrated on the bases of information about final product and process found form history and literature about desired product or similar products. The close association between raw material and process parameters may also lead to, risk factors [86].

\section{Conclusion}

Post-translational glycan modifications during the antibody development exert noteworthy impact on its function, stability, pharmacokinetics, half-life, IgG effector function and on its safety. So, this type of antibody engineering of curative antibodies increases their therapeutic values to combat against pathogenic microbial and autoimmune diseases. However, in this aspect antibody modeling is also needed for further improvement in tools and training expertise. In future, innovations and advancements in antibody engineering may also occur with the use of progressive vaccine (a substance stimulate production of antibodies and provide immunity against diseases) synthesis and genome editing techniques including CRISPR (clustered regularly interspaced short palindromic repeat) to treat various diseases.

\section{Authors' contributions}

Conceived and designed the experiment: $G$ Akbar, MA Zia, A Ahmad, S Ahmad, A Rafique, N Arooj \& S Nusrat, Performed the 
experiment: G Akbar, MA Zia, A Ahmad, S Ahmad, A Rafique, N Arooj \& S Nusrat, Analyzed the data: G Akbar, MA Zia, A Ahmad, S Ahmad, A Rafique, N Arooj \& S Nusrat, Contributed reagents/ materials/ analysis tools: Gm Akbar, MA Zia, A Ahmad, S Ahmad, A Rafique, N Arooj \& S Nusrat, Wrote the paper: G Akbar, MA Zia, A Ahmad, S Ahmad, A Rafique, N Arooj \& S Nusrat.

\section{Acknowledgement}

No financial assistance was obtained for this review paper

\section{References}

1. Raju TS \& Lang SE (2014). Diversity in structure and functions of antibody sialylation in the Fc. Curr Opin Biotechnol 30: 147-152.

2. Kiyoshi M, Tsumoto K, Ishii WA \& Caaveiro JMM (2017). Glycosylation of IgG-Fc: a molecular perspective. Int Immunol 29(7): 311-317.

3. Krapp S, Mimura Y, Jefferis R, Huber R \& Sondermann P (2003). Structural analysis of human IgG-Fc glycoforms reveals a correlation between glycosylation and structural integrity. $J$ Mol Bio 325: 979-989.

4. Elvin JG, Couston RG \& Van DWCF (2013). Therapeutic antibodies: market considerations, disease targets and bioprocessing. Int J Pharm. 440: 83-98.

5. Reichert JM. (2017). Antibodies to watch in 2017. M Ant 9: 167-181.

6. Niwa R \& Satoh M (2015). The current status and prospects of antibody engineering for therapeutic use: focus on glycoengineering technology. J Pharm Sci 104(3): 930-941.

7. Beck A, Wagner RE, Bussat MC, Lokteff M, Klinguer HC \& Haeuw JF (2008). Trends in glycosylation, glycoanalysis and glycoengineering of therapeutic antibodies and Fc-fusion proteins. Curr Pharm Biotech 9: 482501.
8. Feige MJ, Walter S \& Buchner J (2004). Folding mechanism of the $\mathrm{CH} 2$ antibody domain. J Mol Bio 344: 107-118.

9. Zheng K, Bantog C \& Bayer R (2011). The impact of glycosylation on monoclonal antibody conformation and stability. M Ant 3: 568-576.

10. 10 Tao MH \& Morrison SL (1989). Studies of aglycosylated chimeric mouse-human IgG. Role of carbohydrate in the structure and effector functions mediated by the human IgG constant region. J Immunol 143: 2595-2601.

11. Wright A, Sato Y, Okada T, Chang K, Endo T \& Morrison S (2000). In vivo trafficking and catabolism of IgG1 antibodies with Fc associated carbohydrates of differing structure. Glycobiol 10: 1347-1355.

12. Lu RM, Hwang YC, Liu IJ, Lee CC, Tsai $\mathrm{HZ}$, Li HJ \& Wu HC (2020). Development of therapeutic antibodies for the treatment of diseases. $J$ Bio Sci 27(1): 1-30.

13. Ouellette D, Alessandri L, Chi A, Grinnell C, Tarcsa E, Radziejewski C \& Correia I (2010). Studies in serum support rapid formation of disulfide bond between unpaired cysteine residues in the $\mathrm{VH}$ domain of an immunoglobulin G1 molecule. Anal Biochem 397(1): 3747.

14. Yu L, Vizel A, Huff MB, Young M, Remmele JRL \& He B (2006). Investigation of $\mathrm{N}$-terminal glutamate cyclization of recombinant monoclonal antibody in formulation development. $J$ Pharm Biomed Anal 42(4): 455-463.

15. Chelius, D, Jing K, Lueras A, Rehder DS, Dillon TM, Vizel A \& Bondarenko PV (2006). Formation of pyroglutamic acid from N-terminal glutamic acid in immunoglobulin gamma antibodies. Anal Chem 78(7): 2370-2376.

16. Neill A, Nowak C, Patel R, Ponniah G, Gonzalez N, Miano D \& Liu H (2015). 
Characterization of recombinant monoclonal antibody charge variants using OFFGEL fractionation, weak anion exchange chromatography, and mass spectrometry. Anal Chem 87(12): 6204-6211.

17. Ayoub, D, Bertaccini, D, Diemer H, Wagner RE, Colas O, Cianférani S \& Schaeffer RC (2015). Characterization of the N-terminal heterogeneities of monoclonal antibodies using in-gel charge derivatization of $\alpha$-amines and LC-MS/MS. Anal Chem 87(7): 37843790

18. Gibson SJ, Bond NJ, Milne S, Lewis A, Sheriff A, Pettman G \& Hatton D (2017). $\mathrm{N}$-terminal or signal peptide sequence engineering prevents truncation of human monoclonal antibody light chains. Biotech Bio Eng 114(9): 19701977.

19. Liu, YD, Goetze, AM, Bass RB \& Flynn GC (2011). N-terminal glutamate to pyroglutamate conversion in vivo for human IgG2 antibodies. J Biol Chem 286(13): 11211-11217.

20. Cai B, Pan H \& Flynn GC (2011). Cterminal lysine processing of human immunoglobulin G2 heavy chain in vivo. Biotech Bioeng 108(2): 404-412.

21. Harris RJ (1995). Processing of Cterminal lysine and arginine residues of proteins isolated from mammalian cell culture. J chrom A 705(1): 129-134.

22. Moorhouse KG, Nashabeh W, Deveney J, Bjork NS, Mulkerrin MG \& Ryskamp $T$ (1997). Validation of an HPLC method for the analysis of the charge heterogeneity of the recombinant monoclonal antibody IDEC-C2B8 after papain digestion. J Pharm Biomed Anal 16(4): 593-603.

23. Johnson KA, Paisley FK, Tangarone BS, Porter TJ \& Rouse JC (2007). Cation exchange-HPLC and mass spectrometry reveal C-terminal amidation of an IgG1 heavy chain. Anal biochem 360(1): 7583.

24. Tsubaki M, Terashima I, Kamata K, \& Koga A (2013). C-terminal modification of monoclonal antibody drugs: amidated species as a general product-related substance. Int J Bio Macromol 52: 139147.

25. Kaschak T, Boyd D, Lu F, Derfus G, Kluck B, Nogal B \& Yan B (2011). Characterization of the basic charge variants of a human IgG1: effect of copper concentration in cell culture media. $M$ Ant 3(6): 577-583.

26. Tang F, Wang LX \& Huang W (2017). Chemoenzymatic synthesis of glycoengineered $\operatorname{IgG}$ antibodies and glycosite-specific antibody-drug conjugates. Nat Proto 12: 1702-1721.

27. Liu H, Bulseco GG \& Sun J (2006). Effect of posttranslational modifications on the thermal stability of a recombinant monoclonal antibody. Immun let 106(2): 144-153.

28. Antes B, Amon S, Rizzi A, Wiederkum S, Kainer M, Szolar O \& Nechansky A (2007). Analysis of lysine clipping of a humanized Lewis-Y specific Ig G antibody and its relation to $\mathrm{Fc}$-mediated effector function. J Chrom 852(2): 250256.

29. Jiang $\mathrm{G}, \mathrm{Yu} \mathrm{C}$, Yadav $\mathrm{DB}, \mathrm{Hu} \mathrm{Z}$, Amurao, A, Duenas, E \& Chen J (2016). Evaluation of heavy-chain C-terminal deletion on product quality and pharmacokinetics of monoclonal antibodies. J Pharm Sci 105(7): 20662072.

30. Hu Z, Tang D, Misaghi S, Jiang G, Yu C, Yim M \& Shen A (2017). Evaluation of heavy chain $\mathrm{C}$-terminal deletions on productivity and product quality of monoclonal antibodies in Chinese hamster ovary (CHO) cells. Biotech Pro 33(3): 786-794. 
31. Bradbury, AF \& Smyth DG (1991). Peptide amidation. Tre Bioch Sci 16: 112-115.

32. Girardi E, Holdom MD, Davies AM, Sutton BJ \& Beavil AJ (2009). The crystal structure of rabbit IgG-Fc. Biochem J 417(1): 77-83.

33. Matsumiya S, Yamaguchi Y, Saito J, Nagano M, Sasakawa H, Otaki S \& Kato K (2007). Structural comparison of fucosylated and nonfucosylated $\mathrm{Fc}$ fragments of human immunoglobulin G1. J Mol Bio 368(3):767-779.

34. Subedi GP \& Barb AW (2015). The structural role of antibody $\mathrm{N}$ glycosylation in receptor interactions. Str 23: 1573-83.

35. Raju TS (2008). Terminal sugars of Fc glycans influence antibody effector functions of IgGs. Curr Opin Immunol 20(4): 471-478.

36. Quast I, Peschke B \& Lunemann JD (2017). Regulation of antibody effector func-tions through $\mathrm{IgG} \quad \mathrm{Fc} \mathrm{N}$ glycosylation. Cell Mol Life Sci 74: 83747.

37. Chiang AW, Li S, Spahn PN, Richelle A, Kuo CC \& Samoudi M (2016). Modulating carbohydrate-protein interactions through glycoengineering of monoclonal antibodies to impact cancer physiology. Cur Op Str Bio 40: 104-11.

38. Luo C, Chen S, Xu N,Wang C, Sai WB, Zhao W, Li YC, Hu XJ, Tian H, Gao XD \& Yao WB (2017). Glycoengineering of pertuzumab and its impact on the pharmacokinetic/pharmacodynamics properties. Sci Rep 7:463-473.

39. Zhang L, Luo S \& Zhang B (2016). Glycan analysis of therapeutic glycoproteins. M Ant 8(2): 205-215.

40. Lee SJ, Evers S, Roeder D, Parlow AF, Risteli J, Risteli L, Lee YC, Feizi T, Langen H \& Nussenzweig MC (2002). Mannose receptor-mediated regulation of serum glycoprotein homeostasis. Sci 295(5561): 1898-1901.

41. Garcia AT, Espinosa CP, Magallanes PA \& Mancilla R (2016). The mannose receptor is involved in the phagocytosis of mycobacteria-induced apoptotic cells. J Immunol Res 38(4): 47-52.

42. Wright A \& Morrison SL (1998). Effect of C2 associated carbohydrate structure on Ig effector function: studies with chimeric mousehuman IgG1 antibodies in glycosylationmutants of Chinese hamster ovary cells. J Immunol 160(7): 3393-3402.

43. Yang J, Primack R, Frohn M, Wang W, Luan P, Retter MW \& Flynn GC (2015) Impact of glycation on antibody clearance. AAPS J 17(1):237-244.

44. Zhou Q \& Qiu H (2019). The mechanistic impact of N-glycosylation on stability, pharmacokinetics, and immunogenicity of therapeutic proteins. J Pharm Sci 108(4): 1366-1377.

45. Gao B, Long C, Lee W, Zhang Z, Gao X, Landsittel D, Ezzelarab M, Ayares D, Huang Y, Cooper DKC, Wang Y \& Hara $\mathrm{H}$ (2017). Anti-Neu5Gc and anti-nonNeu5Gc antibodies in healthyhumans. PLOS One 12:17-25.

46. Jennewein MF \& Alter G (2017). The immunoregulatory roles of antibody glycosylation. Tre I 38(5): 358-372.

47. Wolf RA, Marx ME, Szalaj L, Kuper JJ \&. Cavanaugh PF (2015). Allergic reactions reported with cetuximab and rituximab infusion. WAO 8(1): 82-88.

48. Billioud V, Sandborn WJ \& Peyrin BL (2011). Loss of response and need for adalimumab dose intensification in Crohn's disease: a systematic review. Am J Gastroenterol 106(4): 674-684.

49. Gisbert JP \& Panes J (2009). Loss of response and requirement of infliximab dose intensification in Crohn's disease: a review. Am J Gastroenterol 104(3): 760767. 
50. Hristodorov D, Fischer R, Joerissen H, Muller TB, Apeler H \& Linden L (2013). Generation and comparative characterization of glycosylated and aglycosylated human IgG1 antibodies. Mol Biotech 53(3): 326-335.

51. Macher BA \& Galili U (2008). The Galalpha1,3Galbeta1,4GlcNAc-R (alpha-Gal) epitope: a carbohydrate of unique evolution and clinical relevance. Biochem Biophy Act 1780(2): 75-88.

52. Steinke JW, Platts MTA \& Commins SP (2015). The alpha-gal story: lessons learned from connecting the dots. $J$ All Cl I 135(3): 589-596.

53. Strasser R, Stadlmann J, Schahs M, Stiegler G, Quendler H, Mach L, Glossl J, Weterings K, Pabst M \& Steinkellner $\mathrm{H}$ (2008). Generation of glycoengineered Nicotiana benthamiana for the production of monoclonal antibodies with a homogeneous human-like Nglycan structure. Plant Biotech J 6(4): 392-402.

54. Hurtado GR \& Davies GJ (2012). Recent structural and mechanistic insights into post-translational enzymatic glycosylation. Curr Opin Chem Biol 16(6): 479-487.

55. Backliwal G, Hildinger M, Chenuet S, Wulhfard S, De Jesus M \& Wurm FM (2008). Rational vector design andmultipathway modulation of HEK 293E cells yield recombinant antibody titers exceeding $1 \mathrm{~g} / \mathrm{l}$ by transient transfection under serum-free conditions. Nucleic Acids Res 36(15): 96-106.

56. Ravindranath $\mathrm{MH}$, Jucaud V \& Ferrone S (2018). Monitoring native HLA-I trimer specific antibodies in Luminex multiplex single antigen bead assay: evaluation of beadsets from different manufacturers. J I Meth 460: 73-125.

57. Sengupta PP, Rudramurthy GR, Ligi M, Jacob SS, Rahman H \& Roy P (2018). Development and evaluation of recombinant antigen and monoclonal antibody based competition ELISA for the serosurveillance of surra in animals. J I Meth 460: 87-92.

58. Li TJ, Cheng JR, Hu BS, Liu Y, Qian GL \& Liu FQ (2008). Construction, production, and characterization of recombinant $\mathrm{scFv}$ antibodies against methamidophos expressed in Pichia pastoris. World J Micro Biotech 24(6): 867-874.

59. Scholler N, Garvik B, Quarles T, Jiang S \& Urban N (2006). Method for generation of in vivo biotinylated recombinant antibodies by yeast mating. J I Meth 317(2): 132-143.

60. Shaheen HH, Prinz B, Chen MT, Pavoor $\mathrm{T}$, Lin S, Houston CNR, Moore R, Stadheim TA \& Zha D (2013). A dualmode surface display system for the maturation and production of monoclonal antibodies in glycoengineered Pichia pastoris. PLoS One 8(7): 70-90

61. Chen WC \& Murawsky CM (2018). Strategies for generating diverse antibody repertoires using transgenic animals expressing human antibodies. Front Immunol 9: 460-468

62. Chung $\mathrm{CH}$, Mirakhur B, Chan E, Le QT, Berlin J, Morse M, Murphy BA, Satinover SM, Hosen J, Mauro D, Slebos RJ, Zhou Q, Gold D, Hatley T, Hicklin DJ \& Platts MTA (2008). Cetuximabinduced anaphylaxis and IgE specific for galactose-alpha-1,3-galactose. $N$ Engl $J$ Med 358(11): 1109-1117.

63. Buettner MJ, Shah SR, Saeui CT, Ariss R \& Yarema KJ (2018). Improving immunotherapy through glycodesign. Front Immunol 9: 2485-2493

64. Chung CY, Wang Q, Yang S, Yin B, Zhang H \& Betenbaugh M (2017). Integrated genome and protein editing swaps alpha-2,6 sialylation for alpha-2,3 
Sialic acid on recombinant antibodies from CHO. Biotechnol J 12(2): 160-168.

65. Zhang N, Liu L, Du MCD, Cummings NRH, Cukan M, Jiang Y, Yuan L, Fang L, Mitchell T \& Mallem MR (2011). Glycoengineered Pichia produced antiHER2 is comparable to trastuzumab in preclinical study. M Ant 3(3): 289-298.

66. Sun T, Li CD, Han L, Jiang H, Xie YQ, Zhang BH, Qian XP, Lu HL \& Zhu JW (2015). Functional knockout of FUT8 in Chinese hamster ovary cells using CRISPR/Cas9 to produced efucosylated antibody. Eng Life Sci 15(6): 660-666.

67. Yamane ON, Kinoshita S, Inoue UM, Kusunoki M, Iida S, Nakano R, Wakitani M, Niwa R, Sakurada M, Uchida K, Shitara K \& Satoh M (2004). Establishment of FUT8 knockout Chinese hamster ovary cells: an ideal host cell line for producing completely defucosylated antibodies with enhanced antibody-dependent cellular cytotoxicity. Biotech Bioeng 87(5): 614622.

68. Zong HF, Han L, Ding K, Wang JX, Sun T, Zhang XY, Cagliero C, Jiang H, Xie YQ, Xu JR, Zhang BH \& Zhu JW (2017). Producing defucosylated antibodies with enhanced in vitro antibodydependent cellular cytotoxicity via FUT8 knockout CHO-S cells. Eng Life Sci 17(7): 801-808.

69. Aghamohseni H, Ohadi K, Spearman M, Krahn N, Moo YM, Scharer JM, Butler M \& Budman HM (2014). Effects of nutrient levels and average culture $\mathrm{pH}$ on the glycosylation pattern of camelidhumanized monoclonal antibody. J Biotechnol 186: 98-109.

70. Seo JS, Kim YJ, Cho JM, Baek E \& Lee GM (2013). Effect of culture $\mathrm{pH}$ on recombinant antibody production by a new human cell line, F2N78, grown in suspension at 33.0 degrees $\mathrm{C}$ and 37.0 degrees C. App Micro Biotech 97(12): 5283-5291.

71. Seo JS, Min BS, Kim YJ, Cho JM, Baek E, Cho MS \& Lee GM (2014). Effect of glucose feeding on the glycosylation quality of antibody produced by a human cell line, F2N78, in fed-batch culture. App Micro Biotech 98(8): 3509-3515.

72. Muthing J, Kemminer SE, Conradt HS, Sagi D, Nimtz M, Karst U \& Peter KJ (2003). Effects of buffering conditions and culture $\mathrm{pH}$ on production rates and glycosylation of clinical phase I antimelanoma mouse IgG3 monoclonal antibody R24. Biotech Bio Eng 83(3): 321-334.

73. Lisacek F, Mariethoz J, Alocci D, Rudd PM, Abrahams JL, Campbell MP, Packer NH, Ståhle J, Widmalm G, Mullen E, Adamczyk B, Rojas MMA, Jin C \& Karlsson NG (2017). Databases and associated tools for glycomics and glycoproteomics. In: Lauc G,Wuhrer M (eds) High-throughput glycomics and glycoproteomics: methods and protocols. Springer New York, New York, NY 235-264.

74. Szabo Z, Guttman A, Bones J \& Karger BL (2011). Rapid high-resolution characterization of functionally important monoclonal antibody Nglycans by capillary electrophoresis. Anal Chem 83(13): 5329-5336.

75. Melmer M, Stangler T, SchiefermeierM, BrunnerW, Toll H, Rupprechter A, Lindner W \& Premstaller A (2010). HILIC analysis of fluorescencelabeled $\mathrm{N}$-glycans from recombinant biopharmaceuticals. Anal Bioanal Chem 398(2): 905-914.

76. Reusch D \& Tejada ML (2015). Fc glycans of therapeutic antibodies as critical quality attributes. Glycobio 25(12): 1325-1334.

77. Maier M, Reusch D, Bruggink C, Bulau P, Wuhrer M \& Molhoj M (2016). 
Applying mini-bore HPAEC-MS/MS for the characterization and quantification of $\mathrm{Fc} \mathrm{N}$-glycans from heterogeneously glycosylated IgGs. $J$ Chroma B Anal Techno Biomed Life Sci 1034: 342-352.

78. Nilsson J (2016). Liquid chromatography-tandem mass spectrometrybased fragmentation analysis of glycopeptides. Gly $J$ 33(3): 261-272.

79. Stadlmann J, Pabst M, Kolarich D, Kunert R \& Altmann F (2008). Analysis of immunoglobulin glycosylation by LC-ESI-MS of glycopeptides and oligosaccharides. Pro 8(14): 2858-2871.

80. Zhao M, Wang J, Luo M, Luo H, Zhao M, Han L, Zhang M, Yang H, Xie Y, Jiang H, Feng L, Lu H \& Zhu J (2018). Rapid development of stable transgene CHO cell lines by CRISPR/Cas9mediated site-specific integration into C12orf35. Appl Micro Biotech 102(14): 6105-6117.

81. Barallobre BJ, Baig F, Fava M, Yin X \& Mayr M (2017). Glycoproteomics of the extracellular matrix: a method for intact glycopeptide analysis using mass spectrometry. $J V E$ 122: 556-574.

82. Zhang L, Luo S \& Zhang B (2016). The use of lectin microarray for assessing glycosylation of therapeutic proteins. $M$ Ant 8(3): 524-525.

83. Guidelines ICH (2009). International conference on harmonization of technical requirements for registration of pharmaceuticals for human use. Pharm Develop. Current step version 4.

84. Alt N, Zhang TY, Motchnik P, Taticek R, Quarmby V, Schlothauer T, Beck H, Emrich T \& Harris RJ. (2016). Determination of critical quality attributes for monoclonal antibodies using quality by design principles. Biologicals 44(5): 291-305.

85. Mc DK, \& Ho K (2012). ICH Q11, Development and manufacture of drug substances (Chemical entities and biotechnological/biological entities). GaBl J 1(4): 142-144.

86. Guidline IHT (2005). Quality risk management. Q9 Cur 4: 408-412. 